\title{
Review \\ Chloride Channels and Transporters: Roles beyond Classical Cellular Homeostatic pH or Ion Balance in Cancers
}

\author{
Hyeong Jae Kim ${ }^{1}\left(\mathbb{D}\right.$, Peter Chang-Whan Lee ${ }^{2, *} \mathbb{C}$ and Jeong Hee Hong ${ }^{1, *(\mathbb{D})}$ \\ 1 Department of Physiology, Lee Gil Ya Cancer and Diabetes Institute, Gachon University, 155 Getbeolro, \\ Yeonsu-gu, Incheon 21999, Korea; lilili1125@naver.com \\ 2 Department of Biomedical Sciences, Lung Cancer Research Center, University of Ulsan College of Medicine, \\ Asan Medical Center, Seoul 05505, Korea \\ * Correspondence: pclee@amc.seoul.kr (P.C.-W.L.); minicleo@gachon.ac.kr (J.H.H.); \\ Tel.: +82-32-899-6682 (J.H.H)
}

Simple Summary: Roles of chloride-associated transporters have been raised in various cancers. Although complicated ion movements, crosstalk among channels/transporters through homeostatic electric regulation, difficulties with experimental implementation such as activity measurement of intracellular location were disturbed to verify the precise modulation of channels/transporters, recently defined cancerous function and communication with tumor microenvironment of chloride channels/transporters should be highlighted beyond classical homeostatic ion balance. Chlorideassociated transporters as membrane-associated components of chloride movement, regulations of transmembrane member 16A, calcium-activated chloride channel regulators, transmembrane member 206, chloride intracellular channels, voltage-gated chloride channels, cystic fibrosis transmembrane conductance regulator, voltage-dependent anion channel, volume-regulated anion channel, and chloride-bicarbonate exchangers are discussed.

check for updates

Citation: Kim, H.J.; Lee, P.C.-W.; Hong, J.H. Chloride Channels and Transporters: Roles beyond Classical Cellular Homeostatic $\mathrm{pH}$ or Ion Balance in Cancers. Cancers 2022, 14, 856. https://doi.org/10.3390/ cancers14040856

Academic Editor: David Wong

Received: 31 December 2021

Accepted: 6 February 2022

Published: 9 February 2022

Publisher's Note: MDPI stays neutral with regard to jurisdictional claims in published maps and institutional affiliations.

Copyright: () 2022 by the authors. Licensee MDPI, Basel, Switzerland. This article is an open access article distributed under the terms and conditions of the Creative Commons Attribution (CC BY) license (https:// creativecommons.org/licenses/by/ $4.0 /)$.

\begin{abstract}
The canonical roles of chloride channels and chloride-associated transporters have been physiologically determined; these roles include the maintenance of membrane potential, $\mathrm{pH}$ balance, and volume regulation and subsequent cellular functions such as autophagy and cellular proliferative processes. However, chloride channels/transporters also play other roles, beyond these classical function, in cancerous tissues and under specific conditions. Here, we focused on the chloride channel-associated cancers and present recent advances in understanding the environments of various types of cancer caused by the participation of many chloride channel or transporters families and discuss the challenges and potential targets for cancer treatment. The modulation of chloride channels/transporters might promote new aspect of cancer treatment strategies.
\end{abstract}

Keywords: chloride channels; chloride-associated transporters; prognostic marker; metastasis; migration and invasion

\section{Chloride Transport}

Electrolytes, such as charged anion chloride, drive cellular electrical shifting energy, which mediates various cellular processes. Intracellular chloride ions are abundant $(5-40 \mathrm{mM})$ as are sodium ions [1]. The movement of chloride is considered to regulate cellular membrane potential, cellular volume, and electrostatic compensation as well as maintain the $\mathrm{pH}$ of cellular or intra-organelles such as lysosomes. In addition to its classical roles, chloride channels participate in modulation of the cellular fate and motility of cancer cells. Therefore, the finding that these channels function in malignant conditions beyond simply transporting chloride is meaningful. This review summarizes the prevalence and roles of several families of chloride channels/transporters associated with malignant environments and might facilitate a better understanding of cancer and aid in the identification 
of potential targeted anticancer agents with scope of chloride channel/transporter-based tumorigenesis.

\section{Membrane-Associated Components of Chloride Movement}

\subsection{Transmembrane Member 16 A}

Transmembrane member (TMEM) 16A (calcium-activated chloride channel; anoctamin 1, ANO1) transports chloride and bicarbonate and plays a role in the proliferation and development of malignant cell types. The expression of TMEM16A has been identified in a broad range of cancers such as non-small cell lung cancer (NSCLC) [2], pancreatic cancer [3], prostate cancer [4], breast cancer [5], colorectal carcinoma [6], gastric cancer [7], glioma [8], glioblastoma [9], esophageal cancer [10], lung cancer [11], hepatocellular carcinoma (HCC) [12], liposarcoma [13], leiomyosarcoma [14], salivary gland cancer [15], and chondroblastoma [16]. Cellular specific mechanism of TMEM16A is extensively reviewed and highlighted in various cancers $[17,18]$. Briefly, TMEM16A positively correlates with epidermal growth factor receptor (EGFR) expression in tumor development [2], and both TMEM16A and EGFR are found in NSCLC tissues. Tumor, node, metastasis (TNM) stage $3+4$ primary NSCLC is positive for TMEM16A and EGFR [2]. Thus, TMEM16A is considered as a potential diagnostic marker for lung cancer. Treatment of TMEM16A inhibitor T16Ainh-A01 or knockdown of TMEM16A inhibits the cellular proliferation and invasion by attenuating EGFR phosphorylation in H1299 lung cancer cells [19]. Knocking down TMEM16A attenuates proliferation and migration by inhibiting phosphoinositide 3-kinase/protein kinase B (PI3K/PKB) and mitogen-activated protein kinase (MAPK) pathways in HCC, HepG2, and SMMC7721 cells [20]. Colorectal cancer (CRC) and HCT116 and DLD-1 cells also express abundant TMEM16A, which is a prognostic factor for patients with CRC [21]. MicroRNA-132 (miR-132) has been identified in nerve tissues of mice, humans, zebrafish, and cattle [22] and it functions as a tumor suppressor in various cancers to prevent metastasis and proliferation [23]. Attenuating TMEM16A through miR-132 decreases cellular proliferation, invasion, and liver metastasis [21]. In addition, bestrophin-1 is also considered as a putative calcium-activated chloride channel such as TMEM16A in epithelial cells such as the cystic fibrosis pancreatic duct cell line, CFPAC-1 [24-28] and it enhances calcium signaling and volume regulation in CRC T-84 cells by participating in proliferation [24]. Bestrophin-1 is also associated with the proliferation of oral squamous cell carcinoma (OSCC) HST-1 cells [27]. Although bestrophin-1 consists of calcium-activated chloride channels that are dependent on or independent of other proteins, it interacts with TMEM16A in normal tissues [29-31].

\subsection{TMEM206}

An acidic milieu is involved in various diseases, such as ischemia, cancer development, and inflammation [32]. Acid-sensitive chloride channels (also known as protonactivated chloride channels, PAC; TMEM206) are expressed in normal and malignant tissues. Protein profiling has revealed that colorectal, breast, and hepatic cancer cells have increased amounts of TMEM206, which plays a key role in cellular responses to acidic conditions [32,33]. Consistent with this concept, silencing TMEM206 attenuates acid-mediated cell death and alleviates acidosis-associated pathologies such as ischemic stroke. The cytoplasmic expression of TMEM206 is associated with CRC development and proliferation. The CRC cell lines SW480 and HCT-116 overexpress TMEM206, which results in enhanced cellular migration, invasion, and proliferation via AKT/ERK phosphorylation [32]. Although the precise mechanism of action of TMEM206 in other cancerous tissues remains unknown, TMEM206 could be considered as a diagnostic marker for CRC.

\subsection{Calcium-Activated Chloride Channel Regulators}

Calcium-activated chloride channel regulators (CLCAs) modulate chloride in epithelia, play critical roles in transporting electrolytes including chloride, modulate function of TMEM16A and its adhesion molecules, and negatively regulate cancer development. 
Nasopharyngeal, breast, and colorectal cancers have low levels of CLCAs [34-38]. The CLCA1 protein is primarily expressed in the small intestine, colon, and appendix. The expressions of CLCA1 and CLCA4 are decreased in intestinal tissues from patients with CRC, the CRC cell lines SW620 and LOVO, and in hormone receptor-positive breast cancer cell line MCF7 cells $[35,37,38]$. CLCA1 is negatively involved in the differentiation of intestinal Caco-2 cells [38]. Low levels of CLCA2 mRNA and protein have been identified in nasopharyngeal carcinoma (NPC) S18 and 5-8F cells, whereas overexpressed CLCA2 inhibits FAK/ERK signaling in these cells [34]. Transduction with p53 induces increased CLCA2 and inhibits the proliferation of breast cancer MCF10A and BT549 cells [36]. Overexpressed CLCA4 inhibits the epithelial-mesenchymal transition (EMT), which is involved in the migration and invasion of CRC cells, whereas CLCA4 depleted by shRNA enhances cellular migratory and invasive ability through enhanced EMT in human mammary epithelial cells $[35,37]$. Although further evidence is needed, CLCA levels could be considered as potential diagnostic biomarkers.

\subsection{Chloride Intracellular Channels}

Chloride intracellular channel 1 (CLIC1; also known as NCC27) belongs to the highly conserved CLIC family of chloride ion channels [39]. It can reside in the cytoplasm and temporarily in plasma and internal cell membranes [40]. CLIC1 participates in various cellular functions, including the maintenance of $\mathrm{pH}$ homeostasis, cell survival, cell cycle regulation, cell volume regulation, membrane potential modulation, and organelle acidification [40-48]. This channel is upregulated in various cancer type such as prostate [46], gallbladder (GBC) [48], colon cancer [47], gastric [49], clear cell renal cell carcinoma [50], and glioblastoma stem cells [51,52]. Overexpressed CLIC1 in patients with HCC [53] positively correlates with HCC proliferation and metastasis [54]. CLIC1 participates in hypoxiainduced colonic carcinoma metastasis via the MAPK/ERK pathway [45]. Moreover, CLIC1 is recruited to the plasma membrane in response to chemotaxis, such as directional treatment with epidermal growth factor (EGF) and mechanotaxis and its ectopic expression of CLIC1 enhances migratory apparatus such as lamellipodia and invadopodia [54]. Hypoxiainduced tumor cells possess irregular microvascular networks and blood flow [55] and can be transformed to promote cancer metastasis [56]. Mechanistically, limited blood perfusion or altered flow due to hypoxic conditions might contribute to the migration and invasion of cancer cells [57]. Upregulated CLIC1 expression correlates with lymph node metastasis and lymphatic invasion [49] as well as lung cancer migration and invasion [40]. Cell growth is promoted by CLIC1 via the MAPK/ERK pathway in prostate cancer [46] and CLIC1 is expressed in pancreatic ductal adenocarcinoma (PDAC) [58] where it plays an important role in promoting cancer cell survival, proliferation, and invasion [46,59]. In various regulatory processes involving CLIC1, small interfering (si)RNAs of CLIC1 induce the downregulation of cell proliferation, growth, and invasiveness of pancreatic cancer cell lines such as PANC- 1 and MIAPaca- 2 compared with control cells [58,60]. Furthermore, CLIC1 is associated with proteasome activator $28 \beta$ (PA28 $\beta$ ), and its specific siRNA downregulates CLIC1 in gastric cancer [61]. A regulatory volume decrease (RVD) is a critical process in cancer cell motility, such as migration and invasion [62]. The CLIC1 inhibitors IAA94 or CLIC1-specific siRNAs ameliorate the RVD and decrease the migration and invasion of CRC LOVO and HT-29 cell lines [45]. The expression of CLIC1 at the mRNA and protein levels is downregulated by miR-124 transfection in the hepatic cancer cell line HepG2 and by hsa-miR-372 transfection in the GBC cell lines G-415, OCUG-1, and SGC-996 [63,64]. The downregulation of CLIC1 reduces cell migration and invasion [63]. The siRNA of CLIC1 enhances expression of the tumor metastasis-related genes annexin A7 and gelsolin, the knockdown of which increases CLIC1 expression in mouse HCC Hca-F and Hca-P cell lines, suggesting that CLIC1 interacts with annexin A7 and gelsolin, and mediates tumor cell migration, invasion, and metastasis [65]. In addition, biguanide-related drugs such as metformin, morocydine, and proguanil inhibit CLIC1 current and dysregulate proliferation and invasiveness in glioblastoma stem cells [66]. Cells and tumors expressing Rab25 
have abundant CLIC3 that co-localizes with active integrin $\alpha 5 \beta 1$ in ovarian cancer A2780 cells [67]. High CLIC4 expression in PDAC together with Indian hedgehog is a proposed metastatic marker of PDAC [68]. In contrast, CLIC2 is expressed in non-cancerous masses and is a potent regulator of tight junctions. The expression of CLIC2 and tight junction proteins is upregulated in non-cancer, compared with cancer cells, and CLIC2 regulates the formation of tight junction proteins such as claudin 1, claudin 5, zonula occludens-1, and occludin [69]. CLIC1 and other types of chloride channels could be potential treatment strategies for cancer and should be considered as novel diagnostic and therapeutic targets for prostate, gastric, gallbladder, colon, pancreas, lymphatic, and lung cancers.

\subsection{Voltage-Gated Chloride Channels}

Voltage-gated chloride channel 3 (CLC-3; also known as CLCN3) is expressed in cell membranes and intracellular vesicles where it exchanges chloride for hydrogen. CLC-3 protein is expressed in prostate carcinoma [70], nasopharyngeal [62], neuroendocrine [71], and brain cells [72] and is significantly overexpressed in HCC, compared with normal control tissues [73]. Moreover, upregulated CLC-3 is associated with HCC tumor size and prognosis [73]. Overexpressed CLC-3 protein participates in cell proliferation and migration. The regulation of cell volume by CLC-3 is involved in the development and metastasis of NPC and prostate cancer $[62,70,74]$. Signaling by Wnt/ $\beta$-catenin contributes to metastasis and adhesion by regulating the EMT process in tumorigenesis $[75,76]$. The expression of CLC-3 is more abundant in tissues at the late stage of CRC and in the CRC LOVO and SW620 compared with that in normal cells. SiRNA-CLC-3 (siCLC-3) inhibits CRC cell viability, proliferation, and metastasis by inhibiting Wnt/ $\beta$-catenin signaling, whereas the Wnt/ $\beta$-catenin activator lithium chloride rescues the effect of siCLC-3 [77]. CLC -3 could be a prognostic marker for HCC, CRC, NPC, and prostate cancer. Patients with breast cancer are treated with tamoxifen, a non-steroidal anticancer agent [78] that inhibits the migration, chloride current, and volume regulatory mechanisms in HCC MHCC97H cells in vitro [79]. The activator of protein kinase C (PKC) phorbol-12-myristate-13 acetate (PMA) inhibits PKC expression in the presence of tamoxifen and reduces the migration of cells with CLC-3 knockdown, suggesting that CLC-3 is involved in the mechanism of anticancer drug and cellular volume regulation [80]. CLC-4 is expressed on the cell surface and intracellular endosomal membranes in the CRC cell lines RKO and LS174 [81]. The migration and invasion of CRC cells is reduced by CLC-4 siRNA or shRNA [82]. Incomplete glucose metabolism results in increased intracellular proton concentrations driven by CLC-4, which maintains a neutral intracellular $\mathrm{pH}$ and the essential proton extrusion mechanism [83]. The regulation of $\mathrm{pH}$ by CLC-4 in the endosomal compartment might participate in promoting invasive ability. Active acidification of large intracellular endosomal vesicles by a vacuolar $\mathrm{H}^{+}$-ATPase promotes proteolysis of the extracellular matrix, activates pro-cathepsin $\mathrm{D}$ which is activated when acidic condition is triggered, and facilitates proteolytic function on the basement membrane [82,84]. $\mathrm{pH}$ regulation in the cytosol and intracellular organelles in RKO cells overexpressing CLC-4 results in resistance to acid-induced cytotoxicity, which is similar to an acidic tumor microenvironment and the enhanced ability of colon cancer cells to migrate [82].

\subsection{Cystic Fibrosis Transmembrane Conductance Regulator}

Cystic fibrosis transmembrane conductance regulator (CFTR) is a cAMP-activated chloride channel that regulates the balance of electrolytes in the respiratory and endocrine systems, exocrine glands, and other tissues. Malfunctioning and/or abnormal expression of CFTR have been found in various types of cancer. The upregulated expression of CFTR is associated with an invasive phenotype in cervical and ovarian carcinomas $[85,86]$. Conversely, the mRNA and protein expression of CFTR are reduced in NPC 5-8F, 6-10B, and HNE-1, compared with normal cells, whereas CFTR knockdown increases NPC cell migration and invasion [87]. Enhanced CFTR protein expression in NPC 5-8F cells increases epithelial markers such as occludin and E-cadherin, and attenuates the mesenchymal 
marker smooth muscle actin [87]. In addition, protein expression of CFTR is decreased in CRC, compared with normal tissues [88]. However, CFTR mRNA overexpression decreases cell proliferation, migration, and invasion in the CRC cell lines HCT116 and CaCo-2 [88]. The results of studies on the roles of CFTR in cancer have been contradictory. Enhanced CFTR expression inhibits various cancerous processes such as EMT in breast carcinoma [89], lung cancer [90], NPC [87], endometrial carcinoma cells [91], prostate cancer [92], and intestinal carcinoma [93]. Cisplatin increases CFTR expression and enhances chemoresistance and the cell viability of prostate cancer tissues compared with chemo-sensitive prostate cancer tissues in vivo and LNCaP cells in vitro [94]. Nicotine is a potential cause of lung cancer and a progressive enhancer of adenocarcinoma cells that inhibits the CFTR protein expression in A549 cells [95]. Although the CFTR gene could act as a tumor suppressor, its roles in various cell types and cancer cells need to be defined.

\subsection{Voltage-Dependent Anion Channels}

The expression of voltage-dependent anion channels (VDACs) on the mitochondrial membrane of all eukaryotes, including mammals [96], is increased in various tumor tissues, such as carcinoma of the breast [97], colon [98], thyroid gland [99], lung [100], pancreas [101], and liver [102] compared with that in normal tissues. The VDAC1, 2, and 3 isotypes of these channels play different roles; VDAC1 and VDAC2 participate in pore formation within the mitochondrial membrane [96] and VDAC3 participates in the regulation of mitochondrial membrane potential [103]. The expression of VDAC is associated with neurodegenerative disorders and muscular and myocardial diseases including various types of cancers [104]. The progression of tumorigenesis is decreased in HeLa cells with depleted VDAC1 [105]. The expression of VDAC1 is more abundant in cancer, A549, and HeLa cells, than in normal WI-38 fibroblasts derived from lung tissue [106], HCC tissues, HepG2 and SMMC7721 cells, as well as lung adenocarcinoma tumors [107]. Small interfering RNA-VDAC1 and miR-7 downregulate cell growth, proliferation, migration, and invasion in HCC tissues [102], lung cancer A549 cells [100], and cervical cancer HeLa cells [105]. Furthermore, miR-490-3p is significantly associated with the carcinogenesis of various cancers [98], and it can regulate the growth and EMT of HCC cells [108] and the invasiveness of triple-negative breast cancer cells, MDA-MB-231, and MDA-MB-436 [109]. MiR-490-3p downregulates VDAC1 through the mammalian target of rapamycin (mTOR) pathway in CRC tissues and cell lines [98]. The expression of VDAC2 is upregulated in melanoma cells and HCC cell lines such as HepG2 [110] but downregulated in glioma stem cells [111] and it plays an anti-apoptotic role in primary cultured mouse embryonic fibroblasts. Although its different role of VDACs is defined, precise roles of VDAC family in different cancers remain unresolved and await identification in future studies.

\subsection{Volume-Regulated Anion Channel}

Volume regulation is critical function to maintain cellular fate. Volume-regulated anion channels (VRACs; also called volume-sensitive organic osmolyte anion channel or swelling-induced chloride current $\mathrm{ICl}_{\text {swell }}$ ) are considered as regulatory channels of cellular volume [112]. VRAC is involved in the RVD and regulates proliferation of nasopharyngeal carcinoma cell [113-115], OSCC HST-1 cells [27], and gastric cancer [116]. Inhibited VRAC by 4-(2-Butyl-6,7-dichlor-2-cyclopentyl-indan-1-on-5-yl) oxybutyric acid (DCPIB) reduces proliferation, migration, and invasion of glioblastoma U251 and U87 cells [117]. Leucinerich-repeat-containing 8A (LRRC8A, also called SWELL1) is component protein of VRAC. LRRC8A expresses in HCC tissues and induced cellular proliferation and migration in HCC SMMC-7721, Sk-hep-1, Huh7, and HCCLM3 cells [118]. Moreover, survival of cisplatinresistant A549 cells or A2780 cells is modulated by the LRRC8A [119,120]. Although dual function of VRAC components LRRC8A and LRRC8D on drug resistance has been addressed [121], VRACs may be associated with chemo-resistant mechanism and are needed to verify its precise mechanism in various cancers. 


\subsection{Chloride-Bicarbonate Exchangers}

Chloride-bicarbonate (CB) exchangers consist of solute carrier (SLC) families, including anion exchangers (AEs) and SLC26As. The CB exchangers mediate the electroneutral or electrogenic exchange of bicarbonate for chloride (respective stoichiometry of chloride: bicarbonate, 1:1 or 1:2) and are associated with the regulation of intracellular $\mathrm{pH}$. The anion exchangers AE1, AE2, AE3, and AE4 [122-125] are expressed in various tissues and localize in the plasma membrane. Both AE1 and AE2 are involved in cancer whereas other AEs are unknown. Histologic findings have shown that AE1 is expressed in the cytoplasm of gastric cancer cells $[126,127]$. Knockdown of AE1 induces the release of p16INK4A and inhibits gastric cancer growth [126,128]. The expression of AE1 positively correlates with cancer size and metastasis [127]. Although the modulation of AE1 expression is poorly verified, miR-24-mediates AE1 attenuation in gastric cancer cells [129]. The expression of AE1 is associated with tumor progression through crosstalk with MAPK and hedgehog signaling pathways in esophageal carcinoma [130]. Although AE2 is expressed in most tissues, it has been addressed that the AE2 gene is highly expressed in HCC cells, gastric, and colorectal cancers [131-135]. An antisense oligonucleotide of AE2 inhibits HCC progression [135]. AE2 is also expressed in ovarian cancer and it participates in tumorigenesis through activation of the mTOR/p70S6K1 pathway [136]. AE2a that is localized in the Golgi apparatus is involved in the malignancy of SW-48 CRC cells [137]. We previously found that the anti-alcoholism agent disulfiram exerts anticancer effects and attenuates the membrane expression of AE2 and the supportive enzyme carbonic anhydrase XII through disturbed homeostatic $\mathrm{pH}$ regulation in lung cancer cells [138]. Our Western blotting findings in vitro also showed that disulfiram attenuated AE2 protein expression and CB exchanging activity in the breast cancer cell lines MDA-MB-231 and MCF-7 [138]. Although anti-cancer effect of disulfiram is addressed, the clinical relevance of AE2 in these cancers and the clinical effects of disulfiram should be verified more precisely in other types of cancer. The role of the SLC26 family in cancerous tissues or mechanisms is not well understood. Chondrodysplasias, chronic chloride diarrhea, and deafness in humans are linked to SLC26A2, SLC26A3, and SLC26A4, respectively [139]. SLC26A3 participates in chloride homeostasis and interactions with CFTR [140]. The expression of SLC26A3 is downregulated and modulated by the stomach-specific $18 \mathrm{kDa}$ antrum mucosal protein in gastric cancer cells [141]. Analyses of gene sets and protein-protein networks have revealed a relationship between SLC26A6 and HCC [142]. However, further detailed investigation is needed to reveal whether any members of the SLC26A family have potential to serve as diagnostic or prognostic markers in cancerous tissues.

\section{Perspectives}

The modulation of chloride channels/transporters in cancers has been considered as challenging issues. Complicated ion movements, crosstalk among channels/transporters, difficulties with experimental implementation, and/or compensation of unidentified mechanisms hamper investigations into ion channels/transporters. For example, studies of intracellular ion channels, not plasma membrane-associated channels, have struggled with technical limitations in terms of verifying physiological roles [143].

Recently, advanced therapeutic candidates of chloride transport were reviewed in various organ diseases such as inflammatory lung disease, osteoporosis, dry eye disorders, hypertension, polycystic kidney disease, and kidney stone [112]. Although approved drugs or preclinical trials of chloride transporters are suggested [112], approaches in multiple cancers remain mostly unknown. Thus, this review would be beneficial to expand developed application of trials through an overview of chloride channel/transporterassociated cancers. Interestingly, several chloride channels/transporters are involved in at least two types of cancer (Figure 1 and Table 1). Although shared chloride channels might not reflect similarity among types of cancer, multiple facets should be considered to verify the roles of transporters and convergent regulation in normal and cancer tissues. Moreover, identifying crosstalk among cancers through shared chloride channels might 
provide valuable clues to metastatic cancer. Although accumulating information about chloride channels and transporters provides both challenges to investigator and potential therapeutic targets against cancer, mechanism of channels and transporters requires further verification. In addition, application of developed chloride transport modulators for cancers should be beneficial to verify off-target effect and toxicity on normal tissue for cancer treatment.

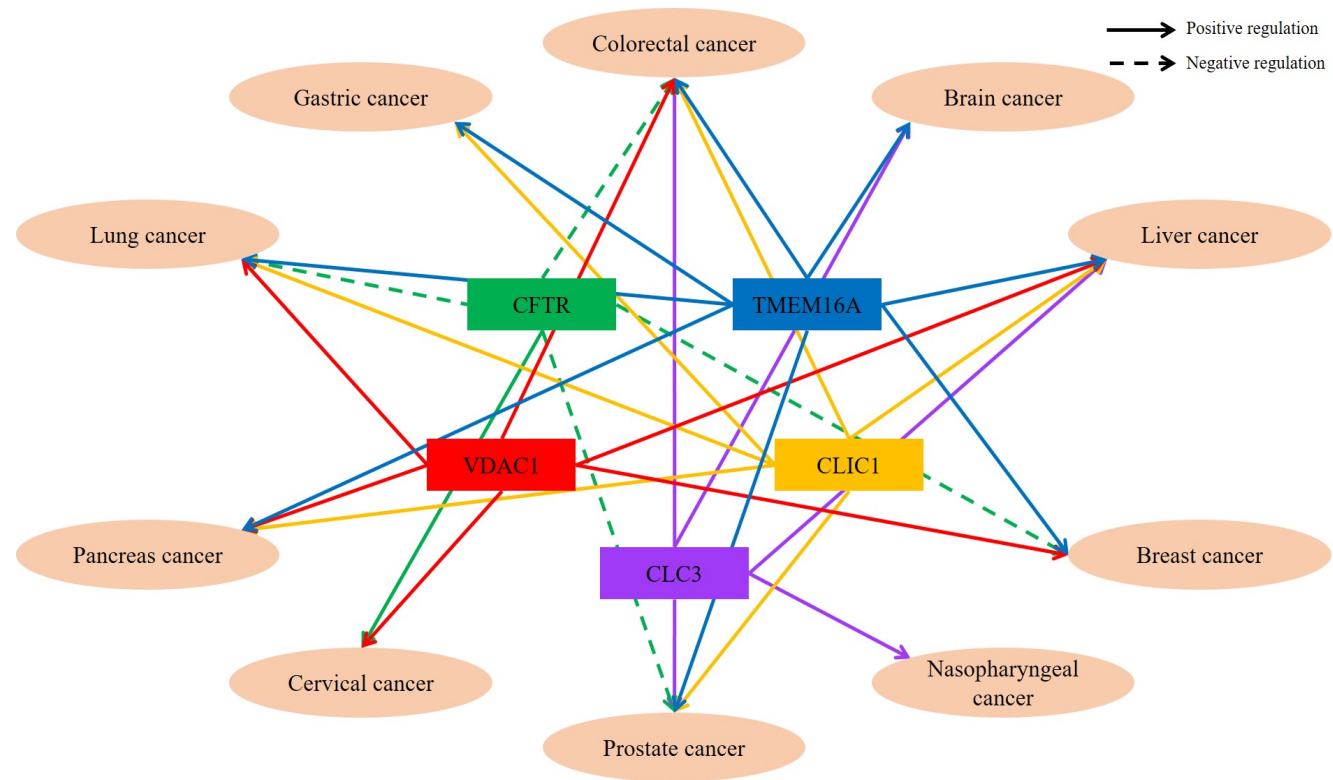

Figure 1. Schema of chloride channel-associated cancers. Chloride channels are involved in at least two types of cancers. Identification of shared chloride channels might provide clues to identify metastatic cancer. VDAC1: Voltage-dependent anion channel 1, TMEM: Transmembrane member, CLC: Voltage-gated chloride channels, CLIC: Chloride intracellular channels, CFTR: Cystic fibrosis transmembrane conductance regulator.

Table 1. Diseases-related chloride channels/transporters and their functions.

\begin{tabular}{|c|c|c|c|}
\hline Diseases & $\begin{array}{c}\text { Chloride } \\
\text { Channels/Transporters }\end{array}$ & Function & Reference \\
\hline \multirow{5}{*}{ Lung cancer } & TMEM16A & $\begin{array}{l}\text { Cell proliferation and development to } \\
\text { malignant tumor } \\
\text { Positive correlation between TMEM16A } \\
\text { and EGFR }\end{array}$ & {$[2,11,19]$} \\
\hline & TMEM206 & $\begin{array}{c}\text { Enhanced cellular migration, invasion, and } \\
\text { proliferation }\end{array}$ & [32] \\
\hline & CLIC1 & Enhanced cellular migration and invasion & [40] \\
\hline & CFTR & $\begin{array}{c}\text { Inhibited various cancer-related processes, } \\
\text { such as EMT }\end{array}$ & {$[90,95]$} \\
\hline & VDAC1 & $\begin{array}{c}\text { Cell growth, proliferation, migration, } \\
\text { and invasion }\end{array}$ & {$[100,107]$} \\
\hline \multirow{4}{*}{ Pancreatic cancer } & TMEM16A & $\begin{array}{l}\text { Cell proliferation and development to } \\
\text { malignant tumor }\end{array}$ & [3] \\
\hline & CLIC1 & $\begin{array}{c}\text { Cell proliferation, growth, and } \\
\text { invasiveness }\end{array}$ & {$[58,60]$} \\
\hline & CLIC4 & Proposed metastatic marker & {$[68]$} \\
\hline & VDAC1 & Cell growth, invasion, and migration & [101] \\
\hline
\end{tabular}


Table 1. Cont.

\begin{tabular}{|c|c|c|c|}
\hline Diseases & $\begin{array}{c}\text { Chloride } \\
\text { Channels/Transporters }\end{array}$ & Function & Reference \\
\hline \multirow{9}{*}{ Hepatic cancer } & TMEM16A & $\begin{array}{l}\text { Cell proliferation and development to } \\
\text { malignant tumor }\end{array}$ & {$[12,20]$} \\
\hline & CLIC1 & $\begin{array}{l}\text { Promoted cancer cell survival, } \\
\text { proliferation, and invasion }\end{array}$ & {$[53,54,59,63,65]$} \\
\hline & CLIC2 & Correlated with the tight junction & [69] \\
\hline & CLC3 & $\begin{array}{l}\text { Related to tumor size and } \\
\text { prognosis marker }\end{array}$ & {$[73,79,80]$} \\
\hline & & Cell volume regulation & \\
\hline & VDAC1 & $\begin{array}{c}\text { Regulated cell growth and EMT } \\
\text { Cell growth, proliferation, migration, } \\
\text { and invasion }\end{array}$ & {$[102,108]$} \\
\hline & VDAC3 & $\begin{array}{l}\text { Regulation of mitochondrial } \\
\text { membrane potential }\end{array}$ & [103] \\
\hline & AE2 & $\begin{array}{l}\text { Inhibited proliferation and viability of } \\
\text { cancer cells }\end{array}$ & {$[131,135]$} \\
\hline & SLC26A6 & $\begin{array}{l}\text { Diagnostic or prognostic biomarker } \\
\text { for cancer }\end{array}$ & [142] \\
\hline \multirow{4}{*}{ Nasopharyngeal cancer } & CLCA2 & $\begin{array}{c}\text { Negatively regulate cancer development } \\
\text { Regulate FAK/ERK signaling }\end{array}$ & {$[34]$} \\
\hline & CLC3 & $\begin{array}{l}\text { Correlation between cell volume regulation } \\
\text { and cancer development and metastasis }\end{array}$ & {$[62,74]$} \\
\hline & CFTR & $\begin{array}{c}\text { Enhanced cell migration and invasion } \\
\text { Regulate EMT }\end{array}$ & [87] \\
\hline & VRAC & Regulates proliferation & [115] \\
\hline \multirow{5}{*}{ Breast cancer } & TMEM16A & $\begin{array}{l}\text { Cell proliferation and development to } \\
\text { malignant tumor }\end{array}$ & {$[5]$} \\
\hline & CLCA2 & Negatively regulate cancer development & [36] \\
\hline & CLCA4 & $\begin{array}{c}\text { Negatively regulate cancer development } \\
\text { Decreased EMT }\end{array}$ & [37] \\
\hline & CFTR & $\begin{array}{l}\text { Inhibited various cancer-related processes, } \\
\text { such as EMT }\end{array}$ & [89] \\
\hline & VDAC1 & Promoted cell proliferation & [97] \\
\hline \multirow{11}{*}{ Colorectal cancer } & TMEM16A & $\begin{array}{l}\text { Cell proliferation and development to } \\
\text { malignant tumor }\end{array}$ & {$[6,21]$} \\
\hline & Bestrophin-1 & Involved in cellular proliferation & [24] \\
\hline & CLCA1 & Negatively regulate cancer development & [38] \\
\hline & CLCA4 & $\begin{array}{c}\text { Negatively regulate cancer development } \\
\text { Decreased EMT }\end{array}$ & [35] \\
\hline & CLIC1 & Enhanced cellular migration and invasion & {$[45,47]$} \\
\hline & CLC3 & $\begin{array}{c}\text { Regulate cell viability, proliferation, and } \\
\text { metastasis }\end{array}$ & [77] \\
\hline & CLC4 & $\begin{array}{l}\text { Regulate invasion, migration, and } \mathrm{pH} \text { of } \\
\text { cytosolic and intracellular organelles }\end{array}$ & {$[81,82]$} \\
\hline & CFTR & $\begin{array}{c}\text { Decreased cell proliferation, migration, } \\
\text { and invasion }\end{array}$ & [88] \\
\hline & VDAC1 & $\begin{array}{l}\text { Regulate apoptosis, proliferation, } \\
\text { migration, and invasion }\end{array}$ & [98] \\
\hline & & Contributed to progression of cancer & \\
\hline & AE2 & $\begin{array}{l}\text { Promote tumor cell malignancy } \\
\text { Responsible for elevated Golgi resting } \mathrm{pH}\end{array}$ & {$[132,137]$} \\
\hline
\end{tabular}


Table 1. Cont.

\begin{tabular}{|c|c|c|c|}
\hline Diseases & $\begin{array}{c}\text { Chloride } \\
\text { Channels/Transporters }\end{array}$ & Function & Reference \\
\hline \multirow{4}{*}{ Prostate cancer } & TMEM16A & $\begin{array}{l}\text { Cell proliferation and development to } \\
\text { malignant tumor }\end{array}$ & {$[4]$} \\
\hline & CLIC1 & $\begin{array}{l}\text { Promoted cancer cell survival, } \\
\text { proliferation, and invasion }\end{array}$ & {$[46]$} \\
\hline & CLC3 & $\begin{array}{l}\text { Correlation between cell volume regulation } \\
\text { and cancer development/ metastasis }\end{array}$ & {$[70]$} \\
\hline & CFTR & $\begin{array}{c}\text { Inhibited various cancer-related processes, } \\
\text { such as EMT } \\
\text { Enhanced chemo-resistance }\end{array}$ & {$[92,94]$} \\
\hline Gallbladder cancer & CLIC1 & Enhanced cellular migration and invasion & {$[48,64]$} \\
\hline \multirow{6}{*}{ Gastric cancer } & TMEM16A & $\begin{array}{c}\text { Cell proliferation and development to } \\
\text { malignant tumor }\end{array}$ & {$[7]$} \\
\hline & CLIC1 & $\begin{array}{l}\text { Enhanced cellular migration and invasion } \\
\text { Involved in release of p16INK } 4 \mathrm{~A} \text { and }\end{array}$ & {$[44,49,61]$} \\
\hline & AE1 & $\begin{array}{l}\text { cell growth } \\
\text { Positive correlation with cancer size } \\
\text { and metastasis }\end{array}$ & [126-129] \\
\hline & AE2 & Contributed to progression of cancer & {$[133,134]$} \\
\hline & SLC26A3 & Interact with AMP18 & [141] \\
\hline & VRAC & Regulates proliferation & [116] \\
\hline \multirow{3}{*}{ Brain tumor } & TMEM16A & $\begin{array}{c}\text { Cell proliferation and development to } \\
\text { malignant tumor }\end{array}$ & {$[8,9]$} \\
\hline & CLC3 & Enhanced cell invasion & [72] \\
\hline & VDAC2 & $\begin{array}{l}\text { Regulator for the metabolic } \\
\text { reprogramming }\end{array}$ & {$[111]$} \\
\hline $\begin{array}{l}\text { Clear cell renal cell } \\
\text { carcinoma }\end{array}$ & CLIC1 & Cell invasion & [50] \\
\hline Neuroendocrine tumor & CLC3 & Enhanced resistance to anticancer drug & [71] \\
\hline \multirow[b]{2}{*}{ Esophageal cancer } & TMEM16A & $\begin{array}{l}\text { Cell proliferation and development to } \\
\text { malignant tumor }\end{array}$ & [10] \\
\hline & AE1 & $\begin{array}{c}\text { Related with tumor progression through } \\
\text { the crosstalk with MAPK and hedgehog } \\
\text { signaling pathways }\end{array}$ & {$[130]$} \\
\hline Liposarcoma & TMEM16A & $\begin{array}{l}\text { Cell proliferation and development to } \\
\text { malignant tumor }\end{array}$ & [13] \\
\hline Leiomyosarcoma & TMEM16A & $\begin{array}{l}\text { Cell proliferation and development to } \\
\text { malignant tumor }\end{array}$ & [14] \\
\hline Salivary gland cancer & TMEM16A & $\begin{array}{l}\text { Cell proliferation and development to } \\
\text { malignant tumor }\end{array}$ & [15] \\
\hline Chondroblastoma & TMEM16A & $\begin{array}{l}\text { Cell proliferation and development to } \\
\text { malignant tumor }\end{array}$ & [16] \\
\hline Hydatidiform moles & CLIC1 & Enhanced cellular migration and invasion & {$[43]$} \\
\hline \multirow{3}{*}{ Ovarian cancer cells } & CLIC3 & $\begin{array}{l}\text { Co-localized with active integrin } \alpha 5 \beta 1 \\
\text { Cell migration and invasion }\end{array}$ & [67] \\
\hline & CFTR & Enhanced cell invasion and migration & [85] \\
\hline & AE2 & $\begin{array}{l}\text { Involved in tumorigenesis through } \\
\text { activation of the mTOR/p70S6K1 pathway }\end{array}$ & {$[136]$} \\
\hline \multirow{2}{*}{ Cervical cancer } & CFTR & Enhanced cell invasion and migration & {$[86]$} \\
\hline & VDAC1 & Regulate progression of tumorigenesis & [105] \\
\hline
\end{tabular}


Table 1. Cont.

\begin{tabular}{|c|c|c|c|}
\hline Diseases & $\begin{array}{c}\text { Chloride } \\
\text { Channels/Transporters }\end{array}$ & Function & Reference \\
\hline \multirow{3}{*}{ Endometrial cancer } & CFTR & $\begin{array}{l}\text { Inhibited various cancer-related processes, } \\
\text { such as EMT }\end{array}$ & {$[91]$} \\
\hline & & Pore-forming role in mitochondrial & \\
\hline & VDAC1 & $\begin{array}{l}\text { membrane } \\
\text { Cell growth, proliferation, migration, and } \\
\text { invasion }\end{array}$ & {$[96]$} \\
\hline $\begin{array}{l}\text { Oral squamous cell } \\
\text { carcinoma }\end{array}$ & $\begin{array}{l}\text { Bestrophin-1 } \\
\text { VRAC }\end{array}$ & $\begin{array}{l}\text { Involved in proliferation } \\
\text { Regulates proliferation }\end{array}$ & [27] \\
\hline
\end{tabular}

Author Contributions: H.J.K., P.C.-W.L. and J.H.H. contributed to the conceptualization and design of the review. H.J.K. collected the information, drafted the article, prepared the figure, and critically revised the manuscript for important intellectual content. J.H.H. and P.C.-W.L. All authors have read and agreed to the published version of the manuscript.

Funding: This study was supported a grant from The National Research Foundation of Korea (NRF) funded by the Korean government (MSIT; NRF-2019R1F1A1046785) to J.H.H. and (NRF2020R1A4A1016029) to P.C.-W.L.

Conflicts of Interest: The authors declare no conflict of interest.

\section{References}

1. Stauber, T.; Jentsch, T.J. Chloride in vesicular trafficking and function. Annu. Rev. Physiol. 2013, 75, 453-477. [CrossRef] [PubMed]

2. He, Y.; Li, H.; Chen, Y.; Li, P.; Gao, L.; Zheng, Y.; Sun, Y.; Chen, J.; Qian, X. Expression of anoctamin 1 is associated with advanced tumor stage in patients with non-small cell lung cancer and predicts recurrence after surgery. Clin. Transl. Oncol. 2017, 19, 1091-1098. [CrossRef] [PubMed]

3. Ardeleanu, C.; Arsene, D.; Hinescu, M.; Andrei, F.; Gutu, D.; Luca, L.; Popescu, L.M. Pancreatic expression of DOG1 a novel gastrointestinal stromal tumor (GIST) biomarker. Appl. Immunohistochem. Mol. Morphol. 2009, 17, 413-418. [CrossRef] [PubMed]

4. Liu, W.; Lu, M.; Liu, B.G.; Huang, Y.; Wang, K.W. Inhibition of $\mathrm{Ca}^{2+}$-activated $\mathrm{Cl}^{-}$channel ANO1/TMEM16A expression suppresses tumor growth and invasiveness in human prostate carcinoma. Cancer Lett. 2012, 326, 41-51. [CrossRef]

5. Ubby, I.; Bussani, E.; Colonna, A.; Stacul, G.; Locatelli, M.; Scudieri, P.; Galietta, L.; Pagani, F. TMEM16A alternative splicing coordination in breast cancer. Mol. Cancer 2013, 12, 75. [CrossRef]

6. Foda, A.M.; Mohamed, M.A. Aberrant expressions of c-KIT and DOG-1 in mucinous and nonmucinous colorectal carcinomas and relation to clinicopathologic features and prognosis. Ann. Diagn. Pathol. 2015, 19, 335-340. [CrossRef]

7. Liu, F.; Cao, Q.H.; Lu, D.J.; Luo, B.; Lu, X.F.; Luo, R.C.; Wang, X.G. TMEM16A overexpression contributes to tumor invasion and poor prognosis of human gastric cancer through TGF-beta signaling. Oncotarget 2015, 6, 11585-11599. [CrossRef]

8. Liu, J.; Liu, Y.; Ren, Y.G.; Kang, L.; Zhang, L.H. Transmembrane protein with unknown function 16A overexpression promotes glioma formation through the nuclear factor-.B signaling pathway. Mol. Med. Rep. 2014, 9, 1068-1074. [CrossRef]

9. Lee, Y.S.; Lee, J.K.; Bae, Y.; Lee, B.S.; Kim, E.; Cho, C.H.; Ryoo, K.; Yoo, J.; Kim, C.H.; Yi, G.S.; et al. Suppression of 14-3-3 gamma-mediated surface expression of ANO1 inhibits cancer progression of glioblastoma cells. Sci. Rep. 2016, 6, 26413. [CrossRef]

10. Shang, L.; Hao, J.J.; Zhao, X.K.; He, J.Z.; Shi, Z.Z.; Liu, H.J.; Wu, L.F.; Jiang, Y.Y.; Shi, F.; Yang, H.; et al. ANO1 protein as a potential biomarker for esophageal cancer prognosis and precancerous lesion development prediction. Oncotarget 2016, 7, 24374-24382. [CrossRef]

11. Jia, L.H.; Liu, W.; Guan, L.Z.; Lu, M.; Wang, K.W. Inhibition of calcium-activated chloride channel ANO1/TMEM16A suppresses tumor growth and invasion in human lung cancer. PLoS ONE 2015, 10, e0136584. [CrossRef] [PubMed]

12. Deng, L.; Yang, J.H.; Chen, H.W.; Ma, B.; Pan, K.M.; Su, C.K.; Xu, F.F.; Zhang, J.H. Knockdown of TMEM16A suppressed MAPK and inhibited cell proliferation and migration in hepatocellular carcinoma. Oncotargets Ther. 2016, 9, 325-333. [CrossRef]

13. Jung, I.; Gurzu, S.; Turdean, S.; Ciortea, D.; Sahlean, D.I.; Golea, M.; Bara, T. Relationship of endothelial area with VEGF-A, COX-2, maspin, c-KIT, and DOG-1 immunoreactivity in liposarcomas versus non-lipomatous soft tissue tumors. Int. J. Clin. Exp. Pathol. 2015, 8, 1776-1782. [PubMed]

14. Sah, S.P.; McCluggage, W.G. DOG1 immunoreactivity in uterine leiomyosarcomas. J. Clin. Pathol. 2013, 66, 40-43. [CrossRef]

15. Abd Raboh, N.M.; Hakim, S.A. Diagnostic role of DOG1 and p63 immunohistochemistry in salivary gland carcinomas. Int. J. Clin. Exp. Pathol. 2015, 8, 9214-9222.

16. Akpalo, H.; Lange, C.; Zustin, J. Discovered on gastrointestinal stromal tumour 1 (DOG1): A useful immunohistochemical marker for diagnosing chondroblastoma. Histopathology 2012, 60, 1099-1106. [CrossRef] 
17. Wang, H.; Zou, L.; Ma, K.; Yu, J.; Wu, H.; Wei, M.; Xiao, Q. Cell-specific mechanisms of TMEM16A Ca ${ }^{2+}$-activated chloride channel in cancer. Mol. Cancer 2017, 16, 152. [CrossRef]

18. Kunzelmann, K.; Ousingsawat, J.; Benedetto, R.; Cabrita, I.; Schreiber, R. Contribution of anoctamins to cell survival and cell death. Cancers 2019, 11, 382. [CrossRef]

19. Hu, C.; Zhang, R.G.; Jiang, D.P. TMEM16A as a potential biomarker in the diagnosis and prognosis of lung cancer. Arch. Iran. Med. 2019, 22, 32-38.

20. Zhang, C.T.; Liu, J.X.; Han, Z.Y.; Cui, X.; Peng, D.T.; Xing, Y.F. Inhibition of TMEM16A suppresses growth and induces apoptosis in hepatocellular carcinoma. Int. J. Clin. Oncol. 2020, 25, 1145-1154. [CrossRef]

21. Mokutani, Y.; Uemura, M.; Munakata, K.; Okuzaki, D.; Haraguchi, N.; Takahashi, H.; Nishimura, J.; Hata, T.; Murata, K.; Takemasa, I.; et al. Down-regulation of microRNA-132 is associated with poor prognosis of colorectal cancer. Ann. Surg. Oncol. 2016, 23, S599-S608. [CrossRef] [PubMed]

22. Qian, Y.; Song, J.; Ouyang, Y.; Han, Q.; Chen, W.; Zhao, X.; Xie, Y.; Chen, Y.; Yuan, W.; Fan, C. Advances in Roles of miR-132 in the nervous system. Front. Pharmacol. 2017, 8, 770. [CrossRef] [PubMed]

23. Wei, X.; Tan, C.; Tang, C.; Ren, G.; Xiang, T.; Qiu, Z.; Liu, R.; Wu, Z. Epigenetic repression of miR-132 expression by the hepatitis B virus x protein in hepatitis B virus-related hepatocellular carcinoma. Cell. Signal. 2013, 25, 1037-1043. [CrossRef] [PubMed]

24. Spitzner, M.; Martins, J.R.; Soria, R.B.; Ousingsawat, J.; Scheidt, K.; Schreiber, R.; Kunzelmann, K. Eag1 and Bestrophin 1 are up-regulated in fast-growing colonic cancer cells. J. Biol. Chem. 2008, 283, 7421-7428. [CrossRef]

25. Bharill, S.; Fu, Z.; Palty, R.; Isacoff, E.Y. Stoichiometry and specific assembly of Best ion channels. Proc. Natl. Acad. Sci. USA 2014, 111, 6491-6496. [CrossRef]

26. Dam, V.S.; Boedtkjer, D.M.; Aalkjaer, C.; Matchkov, V. The bestrophin- and TMEM16A-associated $\mathrm{Ca}^{2+}$-activated $\mathrm{Cl}^{-}$channels in vascular smooth muscles. Channels 2014, 8, 361-369. [CrossRef]

27. Yoshimoto, S.; Matsuda, M.; Kato, K.; Jimi, E.; Takeuchi, H.; Nakano, S.; Kajioka, S.; Matsuzaki, E.; Hirofuji, T.; Inoue, R.; et al Volume-regulated chloride channel regulates cell proliferation and is involved in the possible interaction between TMEM16A and LRRC8A in human metastatic oral squamous cell carcinoma cells. Eur. J. Pharmacol. 2021, 895, 173881. [CrossRef]

28. Marsey, L.L.; Winpenny, J.P. Bestrophin expression and function in the human pancreatic duct cell line, CFPAC-1. J. Physiol. 2009, 587, 2211-2224. [CrossRef]

29. Kunzelmann, K.; Kongsuphol, P.; Aldehni, F.; Tian, Y.; Ousingsawat, J.; Warth, R.; Schreiber, R. Bestrophin and TMEM16-Ca ${ }^{2+}$ activated $\mathrm{Cl}^{-}$channels with different functions. Cell Calcium 2009, 46, 233-241. [CrossRef]

30. Barro-Soria, R.; Aldehni, F.; Almaca, J.; Witzgall, R.; Schreiber, R.; Kunzelmann, K. ER-localized bestrophin 1 activates Ca ${ }^{2+}$ dependent ion channels TMEM16A and SK4 possibly by acting as a counterion channel. Pflug. Arch. Eur. J. Phys. 2010, 459, 485-497. [CrossRef]

31. Liu, Y.; Zhang, H.; Huang, D.; Qi, J.; Xu, J.; Gao, H.; Du, X.; Gamper, N.; Zhang, H. Characterization of the effects of Cl(-) channel modulators on TMEM16A and bestrophin-1 $\mathrm{Ca}^{2+}$ activated $\mathrm{Cl}^{-}$channels. Pflug. Arch. 2015, 467, 1417-1430. [CrossRef] [PubMed]

32. Zhao, J.B.; Zhu, D.H.; Zhang, X.P.; Zhang, Y.; Zhou, J.P.; Dong, M. TMEM206 promotes the malignancy of colorectal cancer cells by interacting with AKT and extracellular signal-regulated kinase signaling pathways. J. Cell. Physiol. 2019, 234, 10888-10898. [CrossRef] [PubMed]

33. Zhang, L.; Liu, S.Y.; Yang, X.; Wang, Y.Q.; Cheng, Y.X. TMEM206 is a potential prognostic marker of hepatocellular carcinoma. Oncol. Lett. 2020, 20, 174. [CrossRef] [PubMed]

34. Qiang, Y.Y.; Li, C.Z.; Sun, R.; Zheng, L.S.; Peng, L.X.; Yang, J.P.; Meng, D.F.; Lang, Y.H.; Mei, Y.; Xie, P.; et al. Along with its favorable prognostic role, CLCA2 inhibits growth and metastasis of nasopharyngeal carcinoma cells via inhibition of FAK/ERK signaling. J. Exp. Clin. Cancer Res. 2018, 37, 34. [CrossRef]

35. Chen, H.; Liu, Y.; Jiang, C.D.; Chen, Y.M.; Li, H.; Liu, Q.A. Calcium-activated chloride channel A4 (CLCA4) plays inhibitory roles in invasion and migration through suppressing epithelial-mesenchymal transition via PI3K/AKT signaling in colorectal cancer. Med. Sci. Monit. 2019, 25, 4176-4185. [CrossRef]

36. Walia, V.; Ding, M.; Kumar, S.; Nie, D.; Premkumar, L.S.; Elble, R.C. hCLCA2 is a p53-inducible inhibitor of breast cancer cell proliferation. Cancer Res. 2009, 69, 6624-6632. [CrossRef]

37. Yu, Y.; Walia, V.; Elble, R.C. Loss of CLCA4 promotes epithelial-to-mesenchymal transition in breast cancer cells. PLoS ONE 2013, 8, e83943. [CrossRef] [PubMed]

38. Yang, B.; Cao, L.; Liu, B.; McCaig, C.D.; Pu, J. The transition from proliferation to differentiation in colorectal cancer is regulated by the calcium activated chloride channel A1. PLoS ONE 2013, 8, e60861. [CrossRef]

39. Wang, W.; Wan, M.H.; Liao, D.J.; Peng, G.L.; Xu, X.; Yin, W.Q.; Guo, G.X.; Jiang, F.N.; Zhong, W.D.; He, J.X. Identification of potent chloride intracellular channel protein 1 inhibitors from traditional chinese medicine through structure-based virtual screening and molecular dynamics analysis. Biomed. Res. Int. 2017, 2017, 4751780. [CrossRef]

40. Wang, W.; Xu, X.; Wang, W.J.; Shao, W.L.; Li, L.P.; Yin, W.Q.; Xiu, L.C.; Mo, M.C.; Zhao, J.; He, Q.Y.; et al. The expression and clinical significance of CLIC1 and HSP27 in lung adenocarcinoma. Tumor Biol. 2011, 32, 1199-1208. [CrossRef]

41. Schlesinger, P.H.; Blair, H.C.; Teitelbaum, S.L.; Edwards, J.C. Characterization of the osteoclast ruffled border chloride channel and its role in bone resorption. J. Biol. Chem. 1997, 272, 18636-18643. [CrossRef] [PubMed]

42. Valenzuela, S.M.; Mazzanti, M.; Tonini, R.; Qiu, M.R.; Warton, K.; Musgrove, E.A.; Campbell, T.J.; Breit, S.N. The nuclear chloride ion channel NCC27 is involved in regulation of the cell cycle. J. Physiol. 2000, 529, 541-552. [CrossRef] [PubMed] 
43. Shi, Z.H.; Zhao, C.; Wu, H.; Wang, W.; Liu, X.M. CLIC1 protein A candidate prognostic biomarker for malignant-transformed hydatidiform Moles. Int. J. Gynecol. Cancer 2011, 21, 153-160. [CrossRef] [PubMed]

44. Ma, P.F.; Chen, J.Q.; Wang, Z.; Liu, J.L.; Li, B.P. Function of chloride intracellular channel 1 in gastric cancer cells. World J. Gastroenterol. 2012, 18, 3070-3080. [CrossRef] [PubMed]

45. Wang, P.; Zhang, C.; Yu, P.W.; Tang, B.; Liu, T.; Cui, H.; Xu, J.H. Regulation of colon cancer cell migration and invasion by CLIC1-mediated RVD. Mol. Cell. Biochem. 2012, 365, 313-321. [CrossRef] [PubMed]

46. Tian, Y.D.; Guan, Y.B.; Jia, Y.Y.; Meng, Q.J.; Yang, J.J. Chloride intracellular channel 1 regulates prostate cancer cell proliferation and migration through the MAPK/ERK pathway. Cancer Biother. Radiopharm. 2014, 29, 339-344. [CrossRef] [PubMed]

47. Wang, P.; Zeng, Y.; Liu, T.; Zhang, C.; Yu, P.W.; Hao, Y.X.; Luo, H.X.; Liu, G. Chloride intracellular channel 1 regulates colon cancer cell migration and invasion through ROS/ERK pathway. World J. Gastroenterol. 2014, 20, 2071-2078. [CrossRef] [PubMed]

48. Ding, Q.C.; Li, M.L.; Wu, X.S.; Zhang, L.; Wu, W.G.; Ding, Q.; Weng, H.; Wang, X.A.; Liu, Y.B. CLIC1 overexpression is associated with poor prognosis in gallbladder cancer. Tumor Biol. 2015, 36, 193-198. [CrossRef]

49. Chen, C.D.; Wang, C.S.; Huang, Y.H.; Chien, K.Y.; Liang, Y.; Chen, W.J.; Lin, K.H. Overexpression of CLIC1 in human gastric carcinoma and its clinicopathological significance. Proteomics 2007, 7, 155-167. [CrossRef]

50. Nesiu, A.; Cimpean, A.M.; Ceausu, R.A.; Adile, A.; Ioiart, I.; Porta, C.; Mazzanti, M.; Camerota, T.C.; Raica, M. Intracellular chloride ion channel protein-1 expression in clear cell renal cell carcinoma. Cancer Genomics Proteomics 2019, 16, $299-307$. [CrossRef]

51. Setti, M.; Savalli, N.; Osti, D.; Richichi, C.; Angelini, M.; Brescia, P.; Fornasari, L.; Carro, M.S.; Mazzanti, M.; Pelicci, G. Functional role of CLIC1 ion channel in glioblastoma-derived stem/progenitor cells. J. Natl. Cancer Inst. 2013, 105, 1644-1655. [CrossRef] [PubMed]

52. Peretti, M.; Raciti, F.M.; Carlini, V.; Verduci, I.; Sertic, S.; Barozzi, S.; Garre, M.; Pattarozzi, A.; Daga, A.; Barbieri, F.; et al. Mutual influence of ROS, $\mathrm{pH}$, and CLIC1 membrane protein in the regulation of G1-S phase progression in human glioblastoma stem cells. Mol. Cancer Ther. 2018, 17, 2451-2461. [CrossRef] [PubMed]

53. Huang, J.S.; Chao, C.C.; Su, T.L.; Yeh, S.H.; Chen, D.S.; Chen, C.T.; Chen, P.J.; Jou, Y.S. Diverse cellular transformation capability of overexpressed genes in human hepatocellular carcinoma. Biochem. Biophys. Res. Commun. 2004, 315, 950-958. [CrossRef] [PubMed]

54. Peng, J.M.; Lin, S.H.; Yu, M.C.; Hsieh, S.Y. CLIC1 recruits PIP5K1A/C to induce cell-matrix adhesions for tumor metastasis. J. Clin. Investig. 2021, 131. [CrossRef] [PubMed]

55. Joyce, J.A.; Pollard, J.W. Microenvironmental regulation of metastasis. Nat. Rev. Cancer 2009, 9, 239-252. [CrossRef]

56. Law, A.Y.; Wong, C.K. Stanniocalcin-2 promotes epithelial-mesenchymal transition and invasiveness in hypoxic human ovarian cancer cells. Exp. Cell Res. 2010, 316, 3425-3434. [CrossRef]

57. Kokura, S.; Yoshida, N.; Imamoto, E.; Ueda, M.; Ishikawa, T.; Uchiyama, K.; Kuchide, M.; Naito, Y.; Okanoue, T.; Yoshikawa, T. Anoxia/reoxygenation down-regulates the expression of E-cadherin in human colon cancer cell lines. Cancer Lett. 2004, 211, 79-87. [CrossRef]

58. Jia, N.N.; Dong, S.L.; Zhao, G.; Gao, H.; Li, X.Q.; Zhang, H.H. CLIC1 overexpression is associated with poor prognosis in pancreatic ductal adenocarcinomas. J. Cancer Res. Ther. 2016, 12, 892-896. [CrossRef]

59. Zhang, S.; Wang, X.M.; Yin, Z.Y.; Zhao, W.X.; Zhou, J.Y.; Zhao, B.X.; Liu, P.G. Chloride intracellular channel 1 is overexpression in hepatic tumor and correlates with a poor prognosis. APMIS 2013, 121, 1047-1053. [CrossRef]

60. Lu, J.H.; Dong, Q.; Zhang, B.T.; Wang, X.F.; Ye, B.; Zhang, F.; Song, X.L.; Gao, G.F.; Mu, J.S.; Wang, Z.; et al. Chloride intracellular channel 1 (CLIC1) is activated and functions as an oncogene in pancreatic cancer. Med. Oncol. 2015, 32, 171. [CrossRef]

61. Zheng, D.L.; Huang, Q.L.; Zhou, F.; Huang, Q.J.; Lin, J.Y.; Lin, X. PA28 ss regulates cell invasion of gastric cancer via modulating the expression of chloride intracellular channel 1. J. Cell Biochem. 2012, 113, 1537-1546. [CrossRef] [PubMed]

62. Mao, J.W.; Chen, L.X.; Xu, B.; Lijing, W.J.; Li, H.Z.; Guo, J.; Li, W.D.; Nie, S.H.; Jacob, T.J.C.; Wang, L.W. Suppression of ClC-3 channel expression reduces migration of nasopharyngeal carcinoma cells. Biochem. Pharmacol. 2008, 75, 1706-1716. [CrossRef] [PubMed]

63. Yue, X.P.; Cui, Y.Y.; You, Q.; Lu, Y.X.; Zhang, J.F. MicroRNA-124 negatively regulates chloride intracellular channel 1 to suppress the migration and invasion of liver cancer cells. Oncol. Rep. 2019, 42, 1380-1390. [CrossRef] [PubMed]

64. Zhou, N.; Cheng, W.; Peng, C.; Liu, Y.; Jiang, B. Decreased expression of hsa-miR-372 predicts poor prognosis in patients with gallbladder cancer by affecting chloride intracellular channel 1. Mol. Med. Rep. 2017, 16, 7848-7854. [CrossRef] [PubMed]

65. Zhang, J.; Li, M.L.; Song, M.Y.; Chen, W.J.; Mao, J.; Song, L.; Wei, Y.Y.; Huang, Y.H.; Tang, J.W. Clic1 plays a role in mouse hepatocarcinoma via modulating Annexin A7 and Gelsolin in vitro and in vivo. Biomed. Pharmacother. 2015, 69, 416-419. [CrossRef]

66. Barbieri, F.; Wurth, R.; Pattarozzi, A.; Verduci, I.; Mazzola, C.; Cattaneo, M.G.; Tonelli, M.; Solari, A.; Bajetto, A.; Daga, A.; et al. Inhibition of chloride intracellular channel 1 (CLIC1) as biguanide class-effect to impair human glioblastoma stem cell viability. Front. Pharmacol. 2018, 9, 899. [CrossRef]

67. Dozynkiewicz, M.A.; Jamieson, N.B.; MacPherson, I.; Grindlay, J.; van den Berghe, P.V.E.; von Thun, A.; Morton, J.P.; Gourley, C.; Timpson, P.; Nixon, C.; et al. Rab25 and CLIC3 collaborate to promote integrin recycling from late endosomes/lysosomes and drive cancer progression. Dev. Cell 2012, 22, 131-145. [CrossRef] 
68. Zou, Q.; Yang, Z.L.; Li, D.Q.; Liu, Z.R.; Yuan, Y. Association of chloride intracellular channel 4 and Indian hedgehog proteins with survival of patients with pancreatic ductal adenocarcinoma. Int. J. Exp. Pathol. 2016, 97, 422-429. [CrossRef]

69. Ueno, Y.; Ozaki, S.; Umakoshi, A.; Yano, H.; Choudhury, M.E.; Abe, N.; Sumida, Y.; Kuwabara, J.; Uchida, R.; Islam, A.; et al Chloride intracellular channel protein 2 in cancer and non-cancer human tissues: Relationship with tight junctions. Tissue Barriers 2019, 7, e1593775. [CrossRef]

70. Lemonnier, L.; Shuba, Y.; Crepin, A.; Roudbaraki, M.; Slomianny, C.; Mauroy, B.; Nilius, B.; Prevarskaya, N.; Skryma, R. Bcl-2dependent modulation of swelling-activated $\mathrm{Cl}$ - current and $\mathrm{ClC}-3$ expression in human prostate cancer epithelial cells. Cancer Res. 2004, 64, 4841-4848. [CrossRef]

71. Weylandt, K.H.; Nebrig, M.; Jansen-Rosseck, N.; Amey, J.S.; Carmena, D.; Wiedenmann, B.; Higgins, C.F.; Sardini, A. CIC-3 expression enhances etoposide resistance by increasing acidification of the late endocytic compartment. Mol. Cancer Ther. 2008, 7 , 2261. [CrossRef]

72. Sontheimer, H. An unexpected role for ion channels in brain tumor metastasis. Exp. Biol. Med. 2008, 233, 779-791. [CrossRef]

73. Cheng, W.; Zheng, S.T.; Li, L.; Zhou, Q.; Zhu, H.P.; Hu, J.; Luo, H.B. Chloride channel 3 (CIC-3) predicts the tumor size in hepatocarcinoma. Acta Histochem. 2019, 121, 284-288. [CrossRef] [PubMed]

74. Xu, B.; Mao, J.W.; Wang, L.W.; Zhu, L.Y.; Li, H.Z.; Wang, W.Z.; Jin, X.B.; Zhu, J.Y.; Chen, L.X. ClC-3 chloride channels are essential for cell proliferation and cell cycle progression in nasopharyngeal carcinoma cells. Acta Biochim. Biophys. Sin. 2010, 42, 370-380. [CrossRef] [PubMed]

75. Fodde, R.; Brabletz, T. Wnt/beta-catenin signaling in cancer stemness and malignant behavior. Curr. Opin. Cell Biol. 2007, 19, 150-158. [CrossRef] [PubMed]

76. Cai, J.C.; Guan, H.Y.; Fang, L.S.; Yang, Y.; Zhu, X.; Yuan, J.; Wu, J.H.; Li, M.F. MicroRNA-374a activates Wnt/beta-catenin signaling to promote breast cancer metastasis. J. Clin. Investig. 2013, 123, 566-579. [CrossRef]

77. Mu, H.L.; Mu, L.J.; Gao, J.F. Suppression of CLC-3 reduces the proliferation, invasion and migration of colorectal cancer through Wnt/beta-catenin signaling pathway. Biochem. Biophys. Res. Commun. 2020, 533, 1240-1246. [CrossRef]

78. Hughes-Davies, L.; Caldas, C.; Wishart, G.C. Tamoxifen: The drug that came in from the cold. Br. J. Cancer 2009, 101, 875-878 [CrossRef]

79. Mao, J.W.; Xu, B.; Li, H.Z.; Chen, L.X.; Jin, X.B.; Zhu, J.Y.; Wang, W.Z.; Zhu, L.Y.; Zuo, W.H.; Chen, W.Q.; et al. Lack of association between stretch-activated and volume-activated $\mathrm{Cl}^{-}$currents in hepatocellular carcinoma cells. J. Cell. Physiol. 2011, 226, 1176-1185. [CrossRef]

80. Mao, J.W.; Yuan, J.; Wang, L.W.; Zhang, H.F.; Jin, X.B.; Zhu, J.Y.; Li, H.Z.; Xu, B.; Chen, L.X. Tamoxifen inhibits migration of estrogen receptor-negative hepatocellular carcinoma cells by blocking the swelling-activated chloride current. J. Cell. Physiol. 2013, 228, 991-1001. [CrossRef]

81. Mohammad-Panah, R.; Ackerley, C.; Rommens, J.; Choudhury, M.; Wang, Y.C.; Bear, C.E. The chloride channel ClC-4 co-localizes with cystic fibrosis transmembrane conductance regulator and may mediate chloride flux across the apical membrane of intestinal epithelia. J. Biol. Chem. 2002, 277, 566-574. [CrossRef]

82. Ishiguro, T.; Avila, H.; Lin, S.Y.; Nakamura, T.; Yamamoto, M.; Boyd, D.D. Gene trapping identifies chloride channel 4 as a novel inducer of colon cancer cell migration, invasion and metastases. Br. J. Cancer 2010, 102, 774-782. [CrossRef]

83. Gatenby, R.A.; Gillies, R.J. Why do cancers have high aerobic glycolysis? Nat. Rev. Cancer 2004, 4, 891-899. [CrossRef] [PubMed]

84. Montcourrier, P.; Mangeat, P.H.; Valembois, C.; Salazar, G.; Sahuquet, A.; Duperray, C.; Rochefort, H. Characterization of very acidic phagosomes in breast-cancer cells and their association with invasion. J. Cell Sci. 1994, 107, 2381-2391. [CrossRef] [PubMed]

85. Xu, J.; Lin, L.B.; Yong, M.; Dong, X.J.; Yu, T.H.; Hu, L.N. Adenovirus-mediated overexpression of cystic fibrosis transmembrane conductance regulator enhances invasiveness and motility of serous ovarian cancer cells. Mol. Med. Rep. 2016, 13, 265-272 [CrossRef] [PubMed]

86. Peng, X.; Wu, Z.; Yu, L.; Li, J.K.; Xu, W.M.; Chan, H.C.; Zhang, Y.; Hu, L.N. Overexpression of cystic fibrosis transmembrane conductance regulator (CFTR) is associated with human cervical cancer malignancy, progression and prognosis. Gynecol. Oncol. 2012, 125, 470-476. [CrossRef] [PubMed]

87. Tu, Z.W.; Chen, Q.; Zhang, J.T.; Jiang, X.H.; Xia, Y.F.; Chan, H.C. CFTR is a potential marker for nasopharyngeal carcinoma prognosis and metastasis. Oncotarget 2016, 7, 76955-76965. [CrossRef] [PubMed]

88. Liu, C.; Song, C.; Li, J.X.; Sun, Q. CFTR functions as a tumor suppressor and is regulated by DNA methylation in colorectal cancer. Cancer Manag. Res. 2020, 12, 4261-4270. [CrossRef]

89. Zhang, J.T.; Jiang, X.H.; Xie, C.; Cheng, H.; Dong, J.D.; Wang, Y.; Fok, K.L.; Zhang, X.H.; Sun, T.T.; Tsang, L.L.; et al. Downregulation of CFTR promotes epithelial-to-mesenchymal transition and is associated with poor prognosis of breast cancer. BBA Mol. Cell Res. 2013, 1833, 2961-2969. [CrossRef]

90. Li, J.; Zhang, J.T.; Jiang, X.H.; Shi, X.S.; Shen, J.F.; Feng, F.L.; Chen, J.Y.; Liu, G.H.; He, P.; Jiang, J.H.; et al. The cystic fibrosis transmembrane conductance regulator as a biomarker in non-small cell lung cancer. Int. J. Oncol. 2015, 46, 2107-2115. [CrossRef]

91. Xia, X.; Wang, J.; Liu, Y.; Yue, M. Lower cystic fibrosis transmembrane conductance regulator (CFTR) promotes the proliferation and migration of endometrial carcinoma. Med. Sci. Monit. 2017, 23, 966-974. [CrossRef] [PubMed]

92. Xie, C.; Jiang, X.H.; Zhang, J.T.; Sun, T.T.; Dong, J.D.; Sanders, A.J.; Diao, R.Y.; Wang, Y.; Fok, K.L.; Tsang, L.L.; et al. CFTR suppresses tumor progression through miR-193b targeting urokinase plasminogen activator (uPA) in prostate cancer. Oncogene 2013, 32, 2282-2291. [CrossRef] [PubMed] 
93. Than, B.L.N.; Linnekamp, J.F.; Starr, T.K.; Largaespada, D.A.; Rod, A.; Zhang, Y.; Bruner, V.; Abrahante, J.; Schumann, A.; Luczak, T.; et al. CFTR is a tumor suppressor gene in murine and human intestinal cancer. Oncogene 2016, 35, 4191-4199. [CrossRef] [PubMed]

94. Zhu, Q.; Li, H.; Liu, Y.; Jiang, L. Knockdown of CFTR enhances sensitivity of prostate cancer cells to cisplatin via inhibition of autophagy. Neoplasma 2017, 64, 709-717. [CrossRef]

95. Li, H.; Ma, N.X.; Wang, J.; Wang, Y.; Yuan, C.; Wu, J.; Luo, M.H.; Yang, J.L.; Chen, J.; Shi, J.; et al. Nicotine induces progressive properties of lung adenocarcinoma A549 cells by inhibiting cystic fibrosis transmembrane conductance regulator (CFTR) expression and plasma membrane localization. Technol. Cancer Res. Treat. 2018, 17, 1533033818809984. [CrossRef]

96. Jozwiak, P.; Ciesielski, P.; Forma, E.; Kozal, K.; Wojcik-Krowiranda, K.; Cwonda, L.; Bienkiewicz, A.; Brys, M.; Krzeslak, A. Expression of voltage-dependent anion channels in endometrial cancer and its potential prognostic significance. Tumour Biol. 2020, 42, 1010428320951057. [CrossRef]

97. Yang, G.; Zhou, D.; Li, J.; Wang, W.; Zhong, W.; Fan, W.; Yu, M.; Cheng, H. VDAC1 is regulated by BRD4 and contributes to JQ1 resistance in breast cancer. Oncol. Lett. 2019, 18, 2340-2347. [CrossRef]

98. Liu, X.; He, B.; Xu, T.; Pan, Y.; Hu, X.; Chen, X.; Wang, S. MiR-490-3p functions as a tumor suppressor by inhibiting oncogene VDAC1 expression in colorectal cancer. J. Cancer 2018, 9, 1218-1230. [CrossRef]

99. Ko, J.H.; Gu, W.; Lim, I.; Zhou, T.; Bang, H. Expression profiling of mitochondrial voltage-dependent anion channel-1 associated genes predicts recurrence-free survival in human carcinomas. PLoS ONE 2014, 9, e110094. [CrossRef]

100. Arif, T.; Vasilkovsky, L.; Refaely, Y.; Konson, A.; Shoshan-Barmatz, V. Silencing VDAC1 expression by siRNA inhibits cancer cell proliferation and tumor growth in vivo. Mol. Ther. Nucleic Acids 2014, 3, e159. [CrossRef]

101. Wang, W.; Zhang, T.; Zhao, W.; Xu, L.; Yang, Y.; Liao, Q.; Zhao, Y. A single talent immunogenic membrane antigen and novel prognostic predictor: Voltage-dependent anion channel 1 (VDAC1) in pancreatic cancer. Sci. Rep. 2016, 6, 33648. [CrossRef]

102. Wang, F.R.; Qiang, Y.; Zhu, L.R.; Jiang, Y.S.; Wang, Y.D.; Shao, X.; Yin, L.; Chen, J.H.; Chen, Z. MicroRNA-7 downregulates the oncogene VDAC1 to influence hepatocellular carcinoma proliferation and metastasis. Tumor Biol. 2016, 37, 10235-10246. [CrossRef]

103. Maldonado, E.N.; Lemasters, J.J. Warburg revisited: Regulation of mitochondrial metabolism by voltage-dependent anion channels in cancer cells. J. Pharmacol. Exp. Ther. 2012, 342, 637-641. [CrossRef]

104. Shoshan-Barmatz, V.; De Pinto, V.; Zweckstetter, M.; Raviv, Z.; Keinan, N.; Arbel, N. VDAC, a multi-functional mitochondrial protein regulating cell life and death. Mol. Asp. Med. 2010, 31, 227-285. [CrossRef] [PubMed]

105. Koren, I.; Raviv, Z.; Shoshan-Barmatz, V. Downregulation of voltage-dependent anion channel-1 expression by RNA interference prevents cancer cell growth in vivo. Cancer Biol. Ther. 2010, 9, 1046-1052. [CrossRef] [PubMed]

106. Simamura, E.; Hirai, K.; Shimada, H.; Koyama, J.; Niwa, Y.; Shimizu, S. Furanonaphthoquinones cause apoptosis of cancer cells by inducing the production of reactive oxygen species by the mitochondrial voltage-dependent anion channel. Cancer Biol. Ther 2006, 5, 1523-1529. [CrossRef] [PubMed]

107. Pernemalm, M.; De Petris, L.; Branca, R.M.; Forshed, J.; Kanter, L.; Soria, J.C.; Girard, P.; Validire, P.; Pawitan, Y.; van den Oord, J.; et al. Quantitative proteomics profiling of primary lung adenocarcinoma tumors reveals functional perturbations in tumor metabolism. J. Proteome Res. 2013, 12, 3934-3943. [CrossRef] [PubMed]

108. Zhang, L.Y.; Liu, M.; Li, X.; Tang, H. miR-490-3p modulates cell growth and epithelial to mesenchymal transition of hepatocellular carcinoma cells by targeting endoplasmic reticulum-Golgi intermediate compartment protein 3 (ERGIC3). J. Biol. Chem. 2013, 288, 4035-4047. [CrossRef] [PubMed]

109. Jia, Z.; Liu, Y.; Gao, Q.; Han, Y.; Zhang, G.; Xu, S.; Cheng, K.; Zou, W. miR-490-3p inhibits the growth and invasiveness in triple-negative breast cancer by repressing the expression of TNKS2. Gene 2016, 593, 41-47. [CrossRef]

110. Maldonado, E.N.; Sheldon, K.L.; DeHart, D.N.; Patnaik, J.; Manevich, Y.; Townsend, D.M.; Bezrukov, S.M.; Rostovtseva, T.K.; Lemasters, J.J. Voltage-dependent anion channels modulate mitochondrial metabolism in cancer cells: Regulation by free tubulin and erastin. J. Biol. Chem. 2013, 288, 11920-11929. [CrossRef]

111. Zhou, K.; Yao, Y.L.; He, Z.C.; Chen, C.; Zhang, X.N.; Yang, K.D.; Liu, Y.Q.; Liu, Q.; Fu, W.J.; Chen, Y.P.; et al. VDAC2 interacts with PFKP to regulate glucose metabolism and phenotypic reprogramming of glioma stem cells. Cell Death Dis. 2018, 9, 988. [CrossRef]

112. Verkman, A.S.; Galietta, L.J.V. Chloride transport modulators as drug candidates. Am. J. Physiol. Cell Physiol. 2021, 321, C932-C946. [CrossRef] [PubMed]

113. Chen, L.; Wang, L.; Zhu, L.; Nie, S.; Zhang, J.; Zhong, P.; Cai, B.; Luo, H.; Jacob, T.J. Cell cycle-dependent expression of volumeactivated chloride currents in nasopharyngeal carcinoma cells. Am. J. Physiol. Cell Physiol. 2002, 283, C1313-C1323. [CrossRef] [PubMed]

114. Wang, L.W.; Chen, L.X.; Zhu, L.Y.; Rawle, M.; Nie, S.H.; Zhang, J.; Ping, Z.; Cai, K.R.; Jacob, T.J.C. Regulatory volume decrease is actively modulated during the cell cycle. J. Cell. Physiol. 2002, 193, 110-119. [CrossRef] [PubMed]

115. Chen, L.X.; Zhu, L.Y.; Jacob, T.J.; Wang, L.W. Roles of volume-activated Cl- currents and regulatory volume decrease in the cell cycle and proliferation in nasopharyngeal carcinoma cells. Cell Prolif. 2007, 40, 253-267. [CrossRef]

116. Kurashima, K.; Shiozaki, A.; Kudou, M.; Shimizu, H.; Arita, T.; Kosuga, T.; Konishi, H.; Komatsu, S.; Kubota, T.; Fujiwara, H.; et al LRRC8A influences the growth of gastric cancer cells via the p53 signaling pathway. Gastric Cancer 2021, 24, 1063-1075. [CrossRef]

117. Wong, R.; Chen, W.; Zhong, X.; Rutka, J.T.; Feng, Z.P.; Sun, H.S. Swelling-induced chloride current in glioblastoma proliferation, migration, and invasion. J. Cell. Physiol. 2018, 233, 363-370. [CrossRef] 
118. Lu, P.; Ding, Q.; Li, X.; Ji, X.; Li, L.; Fan, Y.; Xia, Y.; Tian, D.; Liu, M. SWELL1 promotes cell growth and metastasis of hepatocellular carcinoma in vitro and in vivo. EBioMedicine 2019, 48, 100-116. [CrossRef]

119. Min, X.J.; Li, H.; Hou, S.C.; He, W.; Liu, J.; Hu, B.; Wang, J. Dysfunction of volume-sensitive chloride channels contributes to cisplatin resistance in human lung adenocarcinoma cells. Exp. Biol. Med. 2011, 236, 483-491. [CrossRef]

120. Sorensen, B.H.; Dam, C.S.; Sturup, S.; Lambert, I.H. Dual role of LRRC8A-containing transporters on cisplatin resistance in human ovarian cancer cells. J. Inorg. Biochem. 2016, 160, 287-295. [CrossRef]

121. Planells-Cases, R.; Lutter, D.; Guyader, C.; Gerhards, N.M.; Ullrich, F.; Elger, D.A.; Kucukosmanoglu, A.; Xu, G.; Voss, F.K.; Reincke, S.M.; et al. Subunit composition of VRAC channels determines substrate specificity and cellular resistance to Pt-based anti-cancer drugs. EMBO J. 2015, 34, 2993-3008. [CrossRef] [PubMed]

122. Mueller, T.J.; Morrison, M. Detection of a variant of protein 3, the major transmembrane protein of the human erythrocyte. J. Biol. Chem. 1977, 252, 6573-6576. [CrossRef]

123. Demuth, D.R.; Showe, L.C.; Ballantine, M.; Palumbo, A.; Fraser, P.J.; Cioe, L.; Rovera, G.; Curtis, P.J. Cloning and structural characterization of a human non-erythroid band 3-like protein. EMBO J. 1986, 5, 1205-1214. [CrossRef] [PubMed]

124. Kopito, R.R.; Lee, B.S.; Simmons, D.M.; Lindsey, A.E.; Morgans, C.W.; Schneider, K. Regulation of intracellular pH by a neuronal homolog of the erythrocyte anion exchanger. Cell 1989, 59, 927-937. [CrossRef]

125. Tsuganezawa, H.; Kobayashi, K.; Iyori, M.; Araki, T.; Koizumi, A.; Watanabe, S.I.; Kaneko, A.; Fukao, T.; Monkawa, T.; Yoshida, T.; et al. A new member of the HCO 3-transporter superfamily is an apical anion exchanger of beta-intercalated cells in the kidney. J. Biol. Chem. 2001, 276, 8180-8189. [CrossRef]

126. Shen, W.W.; Wu, J.; Cai, L.; Liu, B.Y.; Gao, Y.; Chen, G.Q.; Fu, G.H. Expression of anion exchanger 1 sequestrates p16 in the cytoplasm in gastric and colonic adenocarcinoma. Neoplasia 2007, 9, 812-819. [CrossRef]

127. Xu, W.Q.; Song, L.J.; Liu, Q.; Zhao, L.; Zheng, L.; Yan, Z.W.; Fu, G.H. Expression of anion exchanger 1 is associated with tumor progress in human gastric cancer. J. Cancer Res. Clin. 2009, 135, 1323-1330. [CrossRef] [PubMed]

128. Suo, W.H.; Zhang, N.; Wu, P.P.; Zhao, L.; Song, L.J.; Shen, W.W.; Zheng, L.; Tao, J.; Long, X.D.; Fu, G.H. Anti-tumour effects of small interfering RNA targeting anion exchanger 1 in experimental gastric cancer. Br. J. Pharmacol. 2012, 165, 135-147. [CrossRef]

129. Wu, J.; Zhang, Y.C.; Suo, W.H.; Liu, X.B.; Shen, W.W.; Tian, H.; Fu, G.H. Induction of anion exchanger-1 translation and its opposite roles in the carcinogenesis of gastric cancer cells and differentiation of K562 cells. Oncogene 2010, 29, 1987-1996. [CrossRef]

130. Shiozaki, A.; Kudou, M.; Ichikawa, D.; Shimizu, H.; Arita, T.; Kosuga, T.; Konishi, H.; Komatsu, S.; Fujiwara, H.; Okamoto, K.; et al. Expression and role of anion exchanger 1 in esophageal squamous cell carcinoma. Oncotarget 2017, 8, 17921-17935. [CrossRef]

131. Wu, T.T.; Hsieh, Y.H.; Wu, C.C.; Tsai, J.H.; Hsieh, Y.S.; Huang, C.Y.; Liu, J.Y. Overexpression of anion exchanger 2 in human hepatocellular carcinoma. Chin. J. Physiol. 2006, 49, 192-198. [PubMed]

132. Song, L.J.; Liu, R.J.; Zeng, Z.; Alper, S.L.; Cui, H.J.; Lu, Y.; Zheng, L.; Yan, Z.W.; Fu, G.H. Gastrin inhibits a novel, pathological colon cancer signaling pathway involving EGR1, AE2, and P-ERK. J. Mol. Med. 2012, 90, 707-718. [CrossRef] [PubMed]

133. Wang, T.; Zhao, L.; Yang, Y.; Tian, H.; Suo, W.H.; Yan, M.; Fu, G.H. EGR1 is critical for gastrin-dependent upregulation of anion exchanger 2 in gastric cancer cells. FEBS J. 2013, 280, 174-183. [CrossRef]

134. Yang, Y.; Wu, P.P.; Wu, J.; Shen, W.W.; Wu, Y.L.; Fu, A.F.; Zheng, L.; Jin, X.L.; Fu, G.H. Expression of anion exchanger 2 in human gastric cancer. Exp. Oncol. 2008, 30, 81-87.

135. Hwang, J.M.; Kao, S.H.; Hsieh, Y.H.; Li, K.L.; Wang, P.H.; Hsu, L.S.; Liu, J.Y. Reduction of anion exchanger 2 expression induces apoptosis of human hepatocellular carcinoma cells. Mol. Cell. Biochem. 2009, 327, 135-144. [CrossRef] [PubMed]

136. Zhang, L.J.; Lu, R.; Song, Y.N.; Zhu, J.Y.; Xia, W.; Zhang, M.; Shao, Z.Y.; Huang, Y.; Zhou, Y.; Zhang, H.; et al. Knockdown of anion exchanger 2 suppressed the growth of ovarian cancer cells via mTOR/p70S6K1 signaling. Sci. Rep. 2017, 7, 6362. [CrossRef] [PubMed]

137. Khosrowabadi, E.; Rivinoja, A.; Risteli, M.; Tuomisto, A.; Salo, T.; Makinen, M.J.; Kellokumpu, S. SLC4A2 anion exchanger promotes tumour cell malignancy via enhancing net acid efflux across golgi membranes. Cell. Mol. Life Sci. 2021, 78, 6283-6304. [CrossRef] [PubMed]

138. Hwang, S.; Shin, D.M.; Hong, J.H. Drug repurposing as an antitumor agent: Disulfiram-mediated carbonic anhydrase 12 and anion exchanger 2 modulation to inhibit cancer cell migration. Molecules 2019, 24, 3409. [CrossRef] [PubMed]

139. Cordat, E.; Reithmeier, R.A. Structure, function, and trafficking of SLC4 and SLC26 anion transporters. Curr. Top. Membr. 2014, 73, 1-67. [CrossRef]

140. Ko, S.B.; Shcheynikov, N.; Choi, J.Y.; Luo, X.; Ishibashi, K.; Thomas, P.J.; Kim, J.Y.; Kim, K.H.; Lee, M.G.; Naruse, S.; et al. A molecular mechanism for aberrant CFTR-dependent $\mathrm{HCO}^{3-}$ transport in cystic fibrosis. EMBO J. 2002, 21, 5662-5672. [CrossRef] [PubMed]

141. Di Stadio, C.S.; Altieri, F.; Miselli, G.; Elce, A.; Severino, V.; Chambery, A.; Quagliariello, V.; Villano, V.; de Dominicis, G.; Rippa, E.; et al. AMP18 interacts with the anion exchanger SLC26A3 and enhances its expression in gastric cancer cells. Biochimie 2016, 121, 151-160. [CrossRef] [PubMed]

142. Zhu, Y.; Huang, Y.; Chen, L.; Guo, L.; Wang, L.; Li, M.; Liang, Y. Up-regulation of SLC26A6 in hepatocellular carcinoma and its diagnostic and prognostic significance. Crit. Rev. Eukaryot. Gene Expr. 2021, 31,79-94. [CrossRef] [PubMed]

143. Gururaja Rao, S.; Patel, N.J.; Singh, H. Intracellular chloride channels: Novel biomarkers in diseases. Front. Physiol. 2020, 11, 96. [CrossRef] [PubMed] 